Original scientific paper - Izvorni znanstveni rad

UDK: 637.344

\title{
Effect of mineral salt replacement on properties of Turkish White cheese
}

doi: $10.15567 /$ mljekarstvo.2018.0106

Ecem Akan*, Ozer Kinik

Ege University Faculty of Agriculture Department of Dairy Technology, Izmir, Turkey

Received - Prispjelo: 03.03.2017.

Accepted - Prihvaćeno: 17.12.2017.

\begin{abstract}
In this study, combinations of different mineral salt replacement for sodium chloride were used in Turkish White cheese production. The effect of sodium chloride substitutes on the physical, chemical and textural characteristics of cheese samples was examined. Five types of brine solution including $\mathrm{NaCl}$ only (K: control) (16\% w/w), only $50 \% \mathrm{NaCl}$ (L) $(8 \% \mathrm{w} / \mathrm{w}), 30 \% \mathrm{CaCl}_{2}$ and $70 \%$ $\mathrm{NaCl}(\mathrm{M})(16 \% \mathrm{w} / \mathrm{w}), 30 \% \mathrm{KCl}$ and $70 \% \mathrm{NaCl}(\mathrm{N})(16 \% \mathrm{w} / \mathrm{w})$, and PanSalt (P) (16\% w/w) were used in cheese production. PanSalt $\left(57 \% \mathrm{NaCl}+28 \% \mathrm{KCl}+12 \% \mathrm{MgSO}_{4}\right)$ is a commercial salt with low sodium content. The characteristics of cheeses determined within the study included the total dry matter, ash, protein, fat, salt, titratable acidity, $\mathrm{pH}$ values, percentage of water soluble nitrogen, percentage of trichloroacetic acid soluble nitrogen and proteose-pepton nitrogen; the sodium, calcium, potassium, phosphorus and magnesium content and the textural characteristics (via a texture profile analysis). In comparison to the control cheese, this substitution showed no significant effect on the comprehensive parameters evaluated. The $\mathrm{Na}, \mathrm{K}, \mathrm{Ca}$ and $\mathrm{P}$ content showed important differences among the cheese samples. The total sodium content of L, M, N and P samples decreased significantly. In regard to this research results it can be said that it is possible to produce low sodium cheese with using proper quantity of mineral salt replacers.
\end{abstract}

Key words: Turkish White cheese, mineral salt replacement, proteolysis, low sodium

\section{Introduction}

Chronic diseases, which are some of the most important public health problems worldwide, are the main causes of human death. Overconsumption of salt is an unhealthy nutritional habit and causes several chronic diseases. Therefore, it is necessary to control salt consumption to combat hypertension and other diseases (Anonymous, 2002). It has been reported that excessive dietary sodium is positively associated with hypertension, which in turn causes cardiovascular diseases (Ayyash and Shah, 2010). The recommended daily intake for salt is $6 \mathrm{~g} \mathrm{NaCl}$ (Kaplan, 2000) and the average daily $\mathrm{NaCl}$ consumption in Turkey is $18 \mathrm{~g}$ (Anonymous, 2011). Foreign institutions and government agencies in Turkey have begun to form new action plans for reducing sodium in foods because of its adverse effect on people's health.
Salt is traditionally used as a preservative and is added to cheeses to control bacterial growth and enzyme activity, and to improve flavor (Guinee and Fox, 2004). In cheese technology, salt has several functions such as preventing deterioration of cheese, extending the shelf life and enhancing the flavour. Sodium is largely consumed as its chloride, and it was estimated that at least $75 \%$ of sodium intake in the industrialized diet originates from $\mathrm{NaCl}$ added to manufactured foods (Mattes and Donnely, 1991). Reducing salt concentration in cheeses results in occurrence of proteolysis, water activity, acidity, an increase in bitterness, a decrease in firmness and irregular fermentation (Ayyash and Shah, 2011a). Accordingly, substitution of $\mathrm{NaCl}$ with other salts has been considered to reduce sodium in cheeses (Ayyash and Shah, 2011a). The main effect of mineral salt replacement is to produce equal 
water activity $\left(\mathrm{a}_{\mathrm{w}}\right)$ in the finished cheese, compared to the full-sodium cheese (Grummer et al., 2012). Therefore, the substitution of $\mathrm{NaCl}$ with mineral salt replacements like potassium chloride, calcium chloride, magnesium chloride, magnesium sulphate and their different combinations are a way to reduce sodium content in cheeses. Potassium chloride $(\mathrm{KCl})$ has been recognized as a potential salt substitute for $\mathrm{NaCl}$ (Petik, 1987). The most commonly investigated sodium replacement is $\mathrm{KCl}$, which has the most similar chemical structure to sodium chloride (Johnson et al., 2009). A mixture of $\mathrm{NaCl}$ and $\mathrm{KCl}$ has been successfully used in various cheeses without any adverse effects on cheese quality (Reddy and Marth, 1995), including Halloumi cheese (Ayyash and Shah, 2010), Kefalograviera cheese (Katsiari et al., 2001), White cheese (Karagözlü et al., 2008), imitation cheese (El-Bakry et al., 2011), Feta cheese (Katsiari et al., 1997, 2000b), fresh Minas cheese (Gomes et al., 2011) and Iranian White cheese (Dorosti et al., 2010). Turkish White cheese is the most frequently produced and consumed cheese in Turkey. Therefore, it is important to reduce sodium levels in White cheese for public health. The aim of this study was to examine the effect of $\mathrm{NaCl}$ substitution with $\mathrm{KCl}, \mathrm{CaCl}_{2}$ and a commercially available low-sodium salt replacement (PanSalt), on the chemical composition, proteolysis and texture of Turkish White cheese.

\section{Material and method}

\section{Material}

Balkan Dairy Product Industry and Trade Company, Izmir, Turkey supplied the whole cow milk. CHOOZIT MA 1150 DCU mesophilic culture (Danisco, Paris, France), consisting of Lactococcus lactis subsp. lactis and Lactococcus lactis subsp. cremoris and CHOOZIT 52 LYO 50 DCU thermophilic culture (Danisco, Paris, France) consisting of Streptococcus thermophilus was obtained from Maysa (Kozyatağı, Istanbul, Turkey). The brine solutions were prepared from rock salt. The commercial salt with low sodium content PanSalt was obtained from Artisan Food (Altunizade, İstanbul, Turkey).

\section{Method}

\section{Cheese production}

Raw cow milk was pasteurized at $95{ }^{\circ} \mathrm{C}$ for 10 min. Pasteurised cow milk was cooled down to $37 \pm 2{ }^{\circ} \mathrm{C}$ and inoculated by recommended amounts used for culture mixture: CHOOZIT MA 1150 DCU mesophilic culture (Danisco, Paris, France), consisting of Lactococcus lactis subsp. lactis and Lactococcus lactis subsp. cremoris, CHOOZIT 52 LYO 50 DCU thermophilic culture (Danisco, Paris, France) consisting of Streptococcus thermophilus. Subsequently 0.25 to $0.3 \mathrm{~g} / \mathrm{L}$ calcium chloride and $0.18 \mathrm{~mL} / \mathrm{L}$ liquid rennet were added. When the $\mathrm{pH}$ value decreased to between 6.10 and 6.15 , curd was cut and the whey was drained for $2 \mathrm{~h}$. Then the curd was held in a press for 2.5 to $3 \mathrm{~h}$. Pressed and drained curd was left for $4 \mathrm{~h}$ in 5 different types of brine solution except sample L (16\% w/w) including $\mathrm{NaCl}$ only (K: control), $50 \% \mathrm{NaCl}(\mathrm{L}), 30 \% \mathrm{CaCl}_{2}$ and

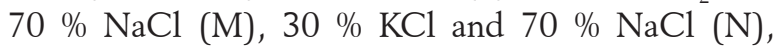
PanSalt $\left(57 \% \mathrm{NaCl}+28 \% \mathrm{KCl}+12 \% \mathrm{MgSO}_{4}\right)(\mathrm{P})$ Then the cheese samples were ripened at room temperature for a night. The next day cheese samples were vacuum packaged and stored for 90 days at $4{ }^{\circ} \mathrm{C}$. White cheeses were produced in the Balkan Dairy Product Industry and Trade Company. On day 1, 30, 60 and 90 of ripening, the physical, chemical, sensory and textural analyses were carried out in a triplicate.

\section{Physicochemical analysis}

The total dry matter of the cheeses was determined according to Anonymous (2006). The fat content of the cheeses was determined by the Gerber method (AOAC, 2000). The $\mathrm{pH}$ values of the cheeses were determined with an inoLab WTW $\mathrm{pH}$ meter (Weilheim, Germany). Titratable acidity values were determined according to Anonymous (2006). The total nitrogen (TN), water-soluble nitrogen (WSN) and soluble nitrogen in $12 \%$ trichloroacetic acid (TCA-SN), and the proteose-peptone nitrogen contents of the samples were determined by the Kjeldahl method. Sample preparation for the Kjeldahl analyses was carried out according to Ardö (1999). The ripening index was estimated as: (WSN/TN) x 100 and (TCA-SN/TN) x 100, respectively. The acid degree value (ADV) was determined according to the method described by Renner (1993). 
Determination of $\mathrm{Na}, \mathrm{K}, \mathrm{Ca}, \mathrm{Mg}$ and $\mathrm{P}$ content of cheeses

The $\mathrm{Na}, \mathrm{K}, \mathrm{Ca}, \mathrm{Mg}$ content of the cheeses was determined by a Perkin Elmer ICP (Optima 2100DV), and $\mathrm{P}$ was determined using UV spectrometry (Specord 50 Analytikjena). Grated cheeses $(2.5 \mathrm{~g})$ were dried in a drying oven at $102{ }^{\circ} \mathrm{C}$ for a night. Then they were dried in a muffle furnace. A $6 \mathrm{~N} \mathrm{HCl}$ solution $(10 \mathrm{~mL})$ was added above the dried samples and were left on a hot plate to dissolve. The dissolved samples were filtered and added to pure water up to $50 \mathrm{ml}$. The diluted solutions produced were kept in the dark (AOAC, 2000).

\section{Texture profile analysis}

A Brookfield Texture Analyzer was used for the textural profile analysis (TPA). Cheese samples of $1.5 \mathrm{~cm}$ in diameter and $2 \mathrm{~cm}$ in height were used for measurements. The cheese samples were wrapped with stretched plastic film to prevent dehydration and kept at a temperature of $20{ }^{\circ} \mathrm{C}$. A two bite penetration test was performed using a TA4/1000 (38.1 mm diameter-20 $\mathrm{mm}$ height) and operated at a crosshead speed of $1 \mathrm{~mm} / \mathrm{s}$ (50\% pressure) and in a downward direction with 2 seconds between the two cycles. Five textural parameters: hardness $(\mathrm{g})$, adhesiveness $(\mathrm{mJ})$, springiness $(\mathrm{mm})$, chewiness $(\mathrm{mJ})$ and gumminess $(\mathrm{g})$ were obtained from the analysis of these force-distance curves. All measurements were done in duplicate during the storage period.

\section{Statistical analysis}

One-way ANOVA was performed to investigate the significant difference at level 0.05 between the experimental cheeses at the storage period intervals. The data obtained was assessed using the SPSS 20.0 for Windows software package. Means were compared using Duncan's multiple-range test with probability $\mathrm{p}<0.05$.

\section{Results and discussion}

\section{Chemical composition}

The effect of using different mineral salt replacements on dry matter, ash, fat and protein content during storage is presented in Table 1. In general, dry matter, protein, ash content changed significantly $(p<0.05)$ during ripening for the same mineral salt replacements. However, the ripening period had no significant effect on the fat content $(p>0.05)$. The effect of mineral salt replacement treatments on the dry matter contents of K, L and P cheeses were not found to be significant at the ninetieth day of storage except for the $\mathrm{M}$ and $\mathrm{N}$ samples. According to the treatments, $\mathrm{M}$ and $\mathrm{P}$ samples contained more dry matter than the others. The increase in dry matter content indicated that more syneresis occurred in these cheeses at the first day of storage. The changes in protein content may be attributed to the proteolytic activity during storage, which resulted in an increase in WSN and TCA-SN in the experimental cheeses. Also the results showed there were no significant differences in chemical composition among experimental White cheeses at the same storage time intervals. Occasional differences were observed between salt treatments in terms of dry matter, protein, ash, and fat contents. It was assumed that these differences were due to variations in cheese blockes and did not relate to mineral salt replacement treatments.

Generally, high moisture content can be explained by an increasing hydration of casein proteins due to the effect of replacement salt (Grummer et al., 2012) and result of high heat treatment of milk used in cheese production. Arakawa and Timasheff (1984) stated that the effect of $\mathrm{Mg}$ salts on protein solubility was strongly affected by $\mathrm{Mg}^{+2}$, whereas this effect was not observed with $\mathrm{NaCl}$, indicating that hydration was also related to a preferential interaction of $\mathrm{MgCl}_{2}$ with protein. In addition, both $\mathrm{Mg}^{+2}$ and $\mathrm{Ca}^{+2}$ salts should tend to increase the solubility more than $\mathrm{Na}^{+}$and could result in more moisture in the cheese and less

ICP Optima 2100 DV working conditions

\begin{tabular}{cc}
\hline Nebulizer pressure: 3 bar & Plasma power: $1,500 \mathrm{~W}$ \\
\hline Plasma flow rate: $15 \mathrm{~L} / \mathrm{dk}$ & Auxilary flow rate: $0.75 \mathrm{~L} / \mathrm{dk}$ \\
\hline Analytcal wavelenghth: & Ca: $318 \mathrm{~nm} \mathrm{Mg:} 279 \mathrm{~nm} \mathrm{K:766} \mathrm{nm} \mathrm{Na:} 590 \mathrm{~nm}$ \\
\hline
\end{tabular}


syneresis (Creighton, 1993; Grummer et al., 2012). However, increased moisture was not determined in cheeses with $\mathrm{CaCl}_{2}$ in our study. Also, dry matter, ash and protein content changed significantly, and a similar fat content could be related to several researchers' findings (Katsiari et al., 1998; Ayyash and Shah, 2010, 2011a, 2011b; Ayyash et al., 2012; Gomes et al., 2011, Ayyash et al., 2011). $\mathrm{KCl}$ has decreased ionic strength compared to $\mathrm{NaCl}$, which results in decreased salting solubility of proteins, which has a direct effect on the cheese matrix (Gomes et al., 2011).

The $\mathrm{pH}$ value of cheeses made with the salt treatments is shown in Table 1 . The $\mathrm{pH}$ values of the cheeses ranged from 4.47 to 4.70 at 1 day of age. The cheeses made with different mineral salt replacements were higher in $\mathrm{pH}$ than the full sodium control sample. The lower $\mathrm{pH}$ (compared with the control group) in $\mathrm{N}$ and $\mathrm{P}$ cheese samples are supported by Reddy and Marth (1995) and
Grummer et al. (2012), who found the $\mathrm{pH}$ to be lower in Cheddar cheese with various $\mathrm{NaCl}$ and $\mathrm{KCl}$ mixtures. Also, other studies in Cheddar, Mozzarella, Halloumi, Akawi, Nabulsi, Feta and Kefalograviera contradict this study in that they report that cheeses with various $\mathrm{NaCl}$ and $\mathrm{KCl}$ mixtures resulted in similar, higher or lower $\mathrm{pH}$ compared with the control (Ayyash and Shah, 2011c; Ayyash et al., 2012 Ayyash et al., 2011a; Ayyash et al., 2013; Katsiari et al., 1997, 1998). In addition, the differences in $\mathrm{pH}$ observed among $\mathrm{CaCl}_{2}$, $\mathrm{NaCl}+\mathrm{KCl}+\mathrm{MgSO}_{4}$ and $\mathrm{NaCl}$ and $\mathrm{KCl}$ in this study might be due to a combination of their differing effects on starter cultures, solubility and interaction with casein in milk, and the lactose content in curd (Grummer et al., 2012; Fitzgerald and Buckley, 1985). The $\mathrm{pH}$ values of cheeses stored in the vacuum packages changed significantly between the salt replacement treatment and the ripening period.

Table 1. Total dry matter, ash, fat, protein contents and $\mathrm{pH}$ values of White cheese made with different salt mineral replacers and stored for $90 \mathrm{~d}$.

\begin{tabular}{|c|c|c|c|c|c|c|}
\hline Attribute & Day & K & $\mathrm{L}$ & M & $\mathrm{N}$ & $\mathrm{P}$ \\
\hline \multirow{4}{*}{$\begin{array}{c}\text { Total dry } \\
\text { matter }(\%)\end{array}$} & 1 & $42.23 \pm 0.44^{\mathrm{Aa}}$ & $43.49 \pm 0.81^{\mathrm{ABb}}$ & $45.64 \pm 0.01^{\mathrm{Ac}}$ & $41.44 \pm 0.40^{\mathrm{ABa}}$ & $44.02 \pm 0.3^{5 \mathrm{Ab}}$ \\
\hline & 30 & $41.44 \pm 0.078^{\mathrm{Ba}}$ & $42.45 \pm 0.07^{\mathrm{Ab}}$ & $43.08 \pm 0.17^{\mathrm{Bc}}$ & $41.07 \pm 0.25^{\mathrm{Aa}}$ & $43.15 \pm 0.01^{\mathrm{Bc}}$ \\
\hline & 60 & $43.24 \pm 0.18^{\mathrm{Ca}}$ & $44.4 \pm 0.51^{\mathrm{Bc}}$ & $43.33 \pm 0.38^{\text {Bab }}$ & $44.26 \pm 0.20^{\mathrm{Cbc}}$ & $43.50 \pm 0.47^{\mathrm{ABabc}}$ \\
\hline & 90 & $41.11 \pm 0.27^{\mathrm{Ba}}$ & $41.1 \pm 0.05^{\mathrm{Ca}}$ & $42.87 \pm 0.29^{\mathrm{Bc}}$ & $42.04 \pm 0.27^{\mathrm{Bb}}$ & $41.42 \pm 0.01^{\mathrm{Ca}}$ \\
\hline \multirow{4}{*}{ Ash (\%) } & 1 & $3.22 \pm 0.06^{\mathrm{Aa}}$ & $2.79 \pm 0.20^{\mathrm{Ab}}$ & $2.62 \pm 0.04^{\mathrm{Ab}}$ & $3.77 \pm 0.03^{\mathrm{Ac}}$ & $2.82 \pm 0.03^{\mathrm{ACb}}$ \\
\hline & 30 & $3.36 \pm 0.15^{\mathrm{Aa}}$ & $2.54 \pm 0.02^{\mathrm{Ab}}$ & $2.63 \pm 0.03^{\mathrm{Ab}}$ & $3.12 \pm 0.12^{\mathrm{Bc}}$ & $2.57 \pm 0.01^{\mathrm{Bb}}$ \\
\hline & 60 & $3.25 \pm 0.08^{\mathrm{Aa}}$ & $2.73 \pm 0.07^{\mathrm{Ab}}$ & $2.69 \pm 0.02^{\mathrm{ABb}}$ & $3.14 \pm 0.01^{\mathrm{Ba}}$ & $2.72 \pm 0.0059^{\mathrm{ABb}}$ \\
\hline & 90 & $3.14 \pm 0.03^{\mathrm{Ca}}$ & $2.52 \pm 0.15^{\mathrm{Aa}}$ & $2.86 \pm 0.10^{\mathrm{Ba}}$ & $3.68 \pm 0.06^{\mathrm{Da}}$ & $2.94 \pm 0.12^{\mathrm{BCa}}$ \\
\hline \multirow{4}{*}{ Fat $(\%)$} & 1 & $20.63 \pm 0.176^{a}$ & $20.50 \pm 0.00^{\mathrm{Aa}}$ & $20.63 \pm 0.17^{\mathrm{Aa}}$ & $20.62 \pm 0.17^{\mathrm{Aa}}$ & $20.62 \pm 0.17^{\mathrm{Aa}}$ \\
\hline & 30 & $20.75 \pm 0.00^{\mathrm{Aa}}$ & $20.88 \pm 0.17^{\mathrm{Ba}}$ & $20.63 \pm 0.17^{\mathrm{Aa}}$ & $20.62 \pm 0.17^{\mathrm{Aa}}$ & $20.62 \pm 0.17^{\mathrm{Aa}}$ \\
\hline & 60 & $19.50 \pm 0.35^{\text {Ва }}$ & $19.63 \pm 0.17^{\mathrm{Ca}}$ & $19.50 \pm 0.00^{\mathrm{Ba}}$ & $19.62 \pm 0.17^{\mathrm{Ba}}$ & $19.50 \pm 0.35^{\mathrm{Ba}}$ \\
\hline & 90 & $18.50 \pm 0.00^{\mathrm{Ca}}$ & $18.81 \pm 0.08^{\mathrm{Dab}}$ & $19.25 \pm 0.35^{\mathrm{Bb}}$ & $18.87 \pm 0.17^{\mathrm{Cab}}$ & $18.75 \pm 0.35^{\mathrm{Bab}}$ \\
\hline \multirow{4}{*}{ Protein (\%) } & 1 & $18.03 \pm 0.77^{\mathrm{ABab}}$ & $18.82 \pm 0.42^{\mathrm{Abc}}$ & $21.56 \pm 0.79^{\mathrm{Bd}}$ & $17.03 \pm 0.04^{\mathrm{Aa}}$ & $20.08 \pm 0.09^{\mathrm{ABC}}$ \\
\hline & 30 & $16.96 \pm 0.76^{\mathrm{Aa}}$ & $18.52 \pm 1.75^{\mathrm{Aab}}$ & $19.32 \pm 0.77^{\mathrm{ABb}}$ & $16.96 \pm 0.67^{\mathrm{Aa}}$ & $19.37 \pm 0.07^{\mathrm{Aab}}$ \\
\hline & 60 & $19.58 \pm 0.62^{\mathrm{B}}$ & $20.62 \pm 0.53^{\mathrm{Aab}}$ & $20.54 \pm 0.05^{\mathrm{ABab}}$ & $20.47 \pm 0.21^{\mathrm{Bab}}$ & $20.98 \pm 0.63^{\mathrm{Bb}}$ \\
\hline & 90 & $18.73 \pm 0.74^{\mathrm{Aba}}$ & $19.83 \pm 0.75^{\mathrm{Aa}}$ & $19.52 \pm 0.79^{\mathrm{Ba}}$ & $19.86 \pm 0.77^{\mathrm{Ba}}$ & $20.12 \pm 0.74^{\mathrm{ABa}}$ \\
\hline \multirow{4}{*}{$\mathrm{pH}$} & 1 & $4.47 \pm 0.01^{\mathrm{Aa}}$ & $4.70 \pm 0.01^{\mathrm{Ac}}$ & $4.52 \pm 0.03^{\mathrm{Aab}}$ & $4.65 \pm 0.03^{\mathrm{Ac}}$ & $4.58 \pm 0.02^{\mathrm{Ab}}$ \\
\hline & 30 & $4.81 \pm 0.00^{\mathrm{Ba}}$ & $4.96 \pm 0.01^{\mathrm{Bb}}$ & $5.18 \pm 0.02^{\mathrm{Bd}}$ & $4.95 \pm 0.01^{\mathrm{Bb}}$ & $4.85 \pm 0.01^{\mathrm{Bb}}$ \\
\hline & 60 & $4.48 \pm 0.06^{\mathrm{Aab}}$ & $4.55 \pm 0.06^{\mathrm{Cb}}$ & $4.40 \pm 0.04^{\mathrm{Ca}}$ & $4.47 \pm 0.07$ Cab & $4.55 \pm 0.03^{\mathrm{Ab}}$ \\
\hline & 90 & $4.46 \pm 0.00^{\mathrm{Ab}}$ & $4.52 \pm 0.00^{\mathrm{cc}}$ & $4.41 \pm 0.01^{\mathrm{Cb}}$ & $4.32 \pm 0.02^{\mathrm{Da}}$ & $4.33 \pm 0.01^{\mathrm{Ca}}$ \\
\hline
\end{tabular}

K: Control (100\% NaCl), L: $50 \% \mathrm{NaCl}, \mathrm{M}: 30 \% \mathrm{CaCl}_{2}+70 \% \mathrm{NaCl}, \mathrm{N}: 30 \% \mathrm{KCl}+70 \% \mathrm{NaCl}, \mathrm{P}:$ PanSalt.

Data are expressed as means \pm SD $p<0.05$. Means followed by different small letters in the row are significantly different $(\mathrm{p}<0.05)$.

Means followed by different capital letters in the columns are significantly different $(\mathrm{p}<0.05)$. 


\section{Assessment of proteolysis}

The measured indicators of proteolysis of cheeses: water soluble nitrogen (WSN), soluble nitrogen in trichloroacetic acid (TCA-SN), proteose-peptone nitrogen, (PP-N) and ripening index values - kept in 5 different brine solutions containing salt replacements are presented in Table 2. The WSN fraction contains small molecules of proteins (noncasein), peptides and free amino acids and is commonly used as a ripening index (Tarakci and Kucukoner, 2006). WSN, TCA-SN, PP-N increased significantly in all the experimental cheeses during the 3 months of storage. It was found that there were no significant differences between the WSN, TCA-SN, PP-N content in all experimental cheeses. Also, the ripening index values in all cheese samples were increased during the storage period. This trend may occur because of the high heat treatment applied to the cheeses during manufacturing and proteolysis. During the ripening period, chymosin residues are considered as a primary proteolytic agent in cheeses. It has also been stated that plasmin and ripening florarelated enzymes (heat stable indigenous enzymes) remained in the cheeses and acted as an important proteolytic agent. The activity of plasmin is slower than that of chymosin (Fox and McSweeney, 1996; Upadhyay et al., 2004; Ayyash and Shah, 2010).

Table 2. WSN, TCA-SN and PPN content and ripening indexes and acid degree values of White cheese samples made with different salt mineral replacers and stored for $90 \mathrm{~d}$.

\begin{tabular}{|c|c|c|c|c|c|c|}
\hline Attribute & Day & $\mathrm{K}$ & $\mathrm{L}$ & M & $\mathrm{N}$ & $\mathrm{P}$ \\
\hline \multirow{4}{*}{ WSN (\%) } & 1 & $0.10 \pm 0.00^{A a}$ & $0.11 \pm 0.03^{\text {Aab }}$ & $0.11 \pm 0.00^{\text {Aab }}$ & $0.12 \pm 0.00^{\mathrm{Ab}}$ & $0.11 \pm 0.00^{\mathrm{Aab}}$ \\
\hline & 30 & $0.18 \pm 0.00^{\mathrm{Bb}}$ & $0.20 \pm 0.00^{\mathrm{Bb}}$ & $0.18 \pm 0.01^{\mathrm{Bb}}$ & $0.15 \pm 0.00^{\mathrm{Aa}}$ & $0.21 \pm 0.00^{\mathrm{Bb}}$ \\
\hline & 60 & $0.21 \pm 0.00^{\mathrm{Ba}}$ & $0.25 \pm 0.01^{\mathrm{Cb}}$ & $0.21 \pm 0.00^{\mathrm{Ba}}$ & $0.24 \pm 0.01^{\mathrm{Bb}}$ & $0.27 \pm 0.00^{\mathrm{Cc}}$ \\
\hline & 90 & $0.27 \pm 0.01^{\mathrm{Ca}}$ & $0.31 \pm 0.00^{\mathrm{Da}}$ & $0.29 \pm 0.00^{\mathrm{Ca}}$ & $0.37 \pm 0.00^{\mathrm{cb}}$ & $0.29 \pm 0.01^{\mathrm{Ca}}$ \\
\hline \multirow{4}{*}{ TCA-SN (\%) } & 1 & $0.07 \pm 0.00^{\mathrm{Aa}}$ & $0.08 \pm 0.00 \mathrm{Aa}$ & $0.08 \pm 0.00^{\mathrm{Aa}}$ & $0.10 \pm 0.03^{\mathrm{Aa}}$ & $0.08 \pm 0.00^{\mathrm{Aa}}$ \\
\hline & 30 & $0.12 \pm 0.00^{\mathrm{Ba}}$ & $0.13 \pm 0.00^{\mathrm{Ba}}$ & $0.13 \pm 0.00^{\mathrm{Ba}}$ & $0.13 \pm 0.00^{\mathrm{Aa}}$ & $0.13 \pm 0.00^{\mathrm{Ba}}$ \\
\hline & 60 & $0.16 \pm 0.00^{\mathrm{cb}}$ & $0.21 \pm 0.00^{\mathrm{Cd}}$ & $0.15 \pm 0.00^{\mathrm{cb}}$ & $0.17 \pm 0.00^{\mathrm{Ac}}$ & $0.14 \pm 0.00^{\mathrm{Ca}}$ \\
\hline & 90 & $0.25 \pm 0.00^{\mathrm{Db}}$ & $0.28 \pm 0.00^{\mathrm{Da}}$ & $0.27 \pm 0.00^{\mathrm{Da}}$ & $0.34 \pm 0.00^{\mathrm{Bb}}$ & $0.28 \pm 0.00^{\mathrm{Db}}$ \\
\hline \multirow{4}{*}{ PPN (\%) } & 1 & $0.08 \pm 0.00^{\mathrm{Aa}}$ & $0.02 \pm 0.00^{\mathrm{Aa}}$ & $0.03 \pm 0.00^{\mathrm{Aa}}$ & $0.19 \pm 0.03^{\mathrm{Aa}}$ & $0.03 \pm 0.00^{\mathrm{Aa}}$ \\
\hline & 30 & $0.06 \pm 0.00^{\mathrm{Bb}}$ & $0.06 \pm 0.00^{\mathrm{Bbc}}$ & $0.05 \pm 0.01^{\mathrm{Bb}}$ & $0.01 \pm 0.00^{\mathrm{ABa}}$ & $0.09 \pm 0.00^{\mathrm{cc}}$ \\
\hline & 60 & $0.05 \pm 0.00^{\mathrm{Ba}}$ & $0.04 \pm 0.00^{\mathrm{BCa}}$ & $0.06 \pm 0.00 \mathrm{~B}^{\mathrm{Ca}}$ & $0.06 \pm 0.01^{\mathrm{BCa}}$ & $0.13 \pm 0.00^{\mathrm{Db}}$ \\
\hline & 90 & $0.03 \pm 0.01^{\mathrm{Ba}}$ & $0.03 \pm 0.00 \mathrm{Dbc}$ & $0.01 \pm 0.00^{\mathrm{Cb}}$ & $0.03 \pm 0.00^{\mathrm{Cc}}$ & $0.10 \pm 0.00^{\mathrm{Bab}}$ \\
\hline \multirow{4}{*}{$\begin{array}{l}\text { Ripening index } \\
\text { [WSN/TN] }\end{array}$} & 1 & $3.70 \pm 0.03^{\mathrm{Aa}}$ & $3.79 \pm 0.05^{\mathrm{Aa}}$ & $3.37 \pm 0.06^{\mathrm{Aa}}$ & $4.5 \pm 0.16^{\mathrm{Ab}}$ & $3.68 \pm 0.00^{\mathrm{Aa}}$ \\
\hline & 30 & $6.98 \pm 0.28^{\mathrm{Ba}}$ & $6.96 \pm 0.33^{\mathrm{Ba}}$ & $6.04 \pm 0.48^{\mathrm{Ba}}$ & $5.66 \pm 0.15^{\mathrm{Ba}}$ & $7.19 \pm 0.03^{\mathrm{Ba}}$ \\
\hline & 60 & $6.84 \pm 0.13^{\text {Ва }}$ & $7.74 \pm 0.31^{\mathrm{Bab}}$ & $6.71 \pm 0.07^{\mathrm{Ba}}$ & $7.57 \pm 0.27 \mathrm{Cab}$ & $8.51 \pm 0.18^{\mathrm{cb}}$ \\
\hline & 90 & $9.45 \pm 0.64^{\mathrm{Ca}}$ & $9.67 \pm 0.03^{\mathrm{Ca}}$ & $9.47 \pm 0.21^{\mathrm{Ca}}$ & $11.96 \pm 0.14^{\mathrm{Db}}$ & $9.33 \pm 0.02^{\mathrm{Da}}$ \\
\hline \multirow{4}{*}{$\begin{array}{l}\text { Ripening index } \\
\text { [TCA-SN/TN] }\end{array}$} & 1 & $2.58 \pm 0.18^{\mathrm{Aa}}$ & $2.91 \pm 0.14^{\mathrm{Aa}}$ & $2.48 \pm 0.06^{\mathrm{Aa}}$ & $3.77 \pm 1.09^{\mathrm{Aa}}$ & $2.95 \pm 0.26^{\mathrm{Aa}}$ \\
\hline & 30 & $4.74 \pm 0.48^{\mathrm{Ba}}$ & $4.80 \pm 0.70^{\mathrm{Ba}}$ & $4.29 \pm 0.37^{\mathrm{Ba}}$ & $5.16 \pm 0.20^{\mathrm{ABa}}$ & $4.26 \pm 0.08^{\mathrm{Ba}}$ \\
\hline & 60 & $5.28 \pm 0.26^{\mathrm{BC}}$ & $6.49 \pm 0.08^{\mathrm{Cd}}$ & $4.78 \pm 0.25^{\mathrm{Bb}}$ & $5.42 \pm 0.03^{\mathrm{Bc}}$ & $4.31 \pm 0.04^{\mathrm{Ca}}$ \\
\hline & 90 & $8.50 \pm 0.62^{\mathrm{Ca}}$ & $9.07 \pm 0.11^{\mathrm{Da}}$ & $8.96 \pm 0.64^{\mathrm{Ca}}$ & $10.85 \pm 0.03^{\mathrm{Cb}}$ & $10.34 \pm 0.39^{\mathrm{Db}}$ \\
\hline \multirow{4}{*}{$\begin{array}{l}\text { Acid degree value } \\
\text { (ADV) }\end{array}$} & 1 & $0.77 \pm 0.10^{\mathrm{Aa}}$ & $0.93 \pm 0.03^{\mathrm{Aab}}$ & $0.99 \pm 0.03^{\mathrm{Ab}}$ & $1.07 \pm 0.05^{\mathrm{Ab}}$ & $0.82 \pm 0.05^{\mathrm{Aa}}$ \\
\hline & 30 & $1.56 \pm 0.08^{\mathrm{Bab}}$ & $1.71 \pm 0.07^{\mathrm{Bbc}}$ & $1.68 \pm 0.08^{\mathrm{Bbc}}$ & $1.80 \pm 0.08^{\mathrm{Bc}}$ & $1.44 \pm 0.08^{\mathrm{Ba}}$ \\
\hline & 60 & $2.68 \pm 0.07^{\mathrm{Ca}}$ & $2.97 \pm 0.02^{\mathrm{Cb}}$ & $2.67 \pm 0.06^{\mathrm{Ca}}$ & $2.18 \pm 0.06^{\mathrm{Ca}}$ & $2.98 \pm 0.06^{\mathrm{Cb}}$ \\
\hline & 90 & $2.06 \pm 0.13^{\mathrm{Da}}$ & $2.68 \pm 0.04^{\mathrm{Dc}}$ & $2.35 \pm 0.06^{\mathrm{Db}}$ & $2.15 \pm 0.06^{\mathrm{Dab}}$ & $2.24 \pm 0.11^{\mathrm{Dab}}$ \\
\hline
\end{tabular}

K: Control (100\% NaCl), L: 50 \% NaCl, M: $30 \% \mathrm{CaCl}_{2}+70 \% \mathrm{NaCl}, \mathrm{N}: 30 \% \mathrm{KCl}+70$ \% NaCl, P: PanSalt.

Data are expressed as means \pm SD $p<0.05$. Means followed by different small letters in the row are significantly different $(\mathrm{p}<0.05)$.

Means followed by different capital letters in the columns are significantly different $(\mathrm{p}<0.05)$. 
As shown in Table 2, in general, significant $(\mathrm{p}<0.05)$ differences were observed between experimental cheeses in WSN at the same point of storage. It was clearly apparent that WSN in cheeses in the $\mathrm{N}$ sample was higher compared to the other samples. This data may support the plasmin activity related to the salt replacement concentrations. These findings are also in accordance with Ayyash and Shah (2010, 2011c) and Ayyash et al. (2012), who showed higher WSN values in Halloumi, Nabulsi and Akawi cheeses stored using different amounts of $\mathrm{NaCl} / \mathrm{KCl}$ containing brine solutions compared with the control during ripening. However, Fitzgerald and Buckley (1985) stated that the highest proteolysis throughout ripening occurred in cheese salted solely with $\mathrm{CaCl}_{2}$ and $\mathrm{MgCl}_{2}$. Trichloroacetic acid soluble nitrogen is known to be an indication of the amount of small peptides and amino acids present in cheese and its level is regarded as the ripening depth index. These peptides and amino acids relate mainly to the action of microorganisms on the caseins and their peptides (Tarakci and Kucukoner, 2006). No significant ( $p>0.05)$ differences in TCA-SN was determined among the experimental cheeses in the first 2 months of the ripening period, whereas a significant $(p<0.05)$ difference was observed at the end of the ripening period in the $\mathrm{N}$ sample that showed higher TCA-SN by comparison with other salt treatments and the control. This change may be explained by the higher WSN of cheese in the $\mathrm{N}$ sample that provided small molecular weight substrates for ripening microflora, and finally by increasing TCA-SN, PP-N. Ayyash and Shah (2010) stated that enzymes from starter culture and non-starter culture flora may hydrolyse peptides resulting from chymosin activity. These findings are in agreement with those of Ayyash and Shah (2010, 2011c), Ayyash et al. (2012), Katsiari et al. (2000a, 2001) who reported similar results in Halloumi, Feta and Kefalogravieria cheeses during ripening, respectively. WSN, TCA-SN and PP-N showed a significant increase during the storage period for the same salt treatment $(p<0.05)$. The formation of WSN and TCA compounds during ripening is an index of the rate and extent of proteolysis, in that it is an indicator of casein hydrolysis brought about by the action of the rennet and the milk proteases present at the beginning of ripening (Tarakci and Kucukoner, 2006). The proteolysis values (WSN/TN) were generally similar among the salt replacement treatments $(p>0.05)$. But, there were significant differences in each of the ripening periods $(p<0.01)$. On the other hand, there were also considerable differences in the degree of proteolysis (expressed as a TCN-SN/TN ratio) in cheeses of the same age that were noted, owing to the variability of several salting substitutes. An increasing ripening index with time is in agreement with the reports of Tarakci and Kucukoner (2006), Mei et al. (2015).

\section{Acid degree value (ADV)}

The extent of the lipolysis of cheeses, expressed as ADV, is shown in Table 2. The ADV of the experimental cheeses increased continuously during the ripening period $(\mathrm{p}<0.05)$. After 60 days of storage ADV of all cheeses decreased. On the other hand, no significant differences in ADV were observed in $\mathrm{K}, \mathrm{L}$ and $\mathrm{P}$, and also between $\mathrm{L}, \mathrm{M}$ and $\mathrm{N}$ cheeses. However, a significant difference was obvious after 3 months of storage compared to the control group $(\mathrm{p}<0.05)$ where cheese subjected to the $\mathrm{L}$ treatment showed higher ADV compared with the other cheeses $(\mathrm{p}<0.05)$. It can be said that lipolysis, as measured by free fatty acid development, was highest for the $\mathrm{L}$ cheese sample followed by the $\mathrm{M}$ and P samples. Compared to our results, Ayyash et al. (2012) reported that the ADV of Akawi cheese did not change significantly in the experimental cheeses. These results are also not in accordance with findings reported by Fitzgerald and Buckley (1985) in Cheddar cheese. A slow rate of lipolysis was related to salt content which has an inhibitory effect on lipase. Generally, ADV increased during ripening and this increase was due to proteolysis, lipolysis and post acidification. Environmental conditions such as salt, lactic acid bacteria, and native milk lipase and protease, were partly responsible for the hydrolysis of lipids and protein in cheese (Shabab Lavasani and Ehsani, 2012). On the other hand, free fatty acids play important roles as precursors of volatile compounds such as ketones, lactones, alcohols and esters. Also, the accumulation of free fatty acids during cheese ripening is considered an overall measure of lipolysis. Long-chain fatty acids do not substantially contribute to cheese flavor due to their high perception threshold (Mei et al., 2015). 


\section{Total Na, K, Ca and P content}

The concentrations $(\mathrm{mg} / \mathrm{l00g})$ of $\mathrm{Na}, \mathrm{K}, \mathrm{Ca}$ and $\mathrm{P}$ in five experimental cheeses during ripening are presented in Table 3. As seen from Table 3, both $\mathrm{Na}$ and $K$ content increased significantly $(\mathrm{p}<0.05)$ during ripening for the same salt treatment. Moreover, a significant $(\mathrm{p}<0.05)$ difference in $\mathrm{Na}$ and $\mathrm{K}$ content was observed between the experimental cheeses on the same sampling day. These results agree with those of Fitzgerald and Buckley (1985) Katsiari et al. (1998), Ayyash and Shah (2010) and Ayyash et al. (2012) who reported similar results in Halloumi, Nabulsi, Akawi, Cheddar and Kefalograviera cheeses. As expected, the sodium content decreased $(p<0.05)$ in White cheese after substituting the $\mathrm{NaCl}$ with other salt mixtures such as $\mathrm{KCl}, \mathrm{CaCl}_{2}$ and $\mathrm{MgSO}_{4}$. The sodium content gradually decreased in the order of treatment $\mathrm{P}<\mathrm{N}<\mathrm{L}=\mathrm{M}$ compared to the control sample after 90 days of ripening.

Potassium contents in $\mathrm{N}, \mathrm{M}$ and $\mathrm{P}$ cheeses were significantly higher compared to the control.
This may be attributed to higher penetrations of salt replacements such as $\mathrm{KCl}, \mathrm{CaCl}_{2}$ and $\mathrm{MgSO}_{4}$ compared to $\mathrm{NaCl}$ in the cheese. The calcium content in the experimental cheese samples changed significantly $(\mathrm{p}<0.05)$ during storage and between cheeses salted with different salt mixtures. Potassium content in cheeses increased slightly $(\mathrm{p}<0.05)$ during the ripening period, with significant differences between cheeses at the first month of the ripening period $(p<0.05)$. Moreover, a significant difference in potassium content was observed between the experimental cheeses at 2 and 3 months of ripening except for the control and L group $(\mathrm{p}<0.05)$. These results do not agree with those of Ayyash and Shah (2010, 2011a) and Ayyash et al. (2012) who reported that the reduction may be due to the migration of calcium and potassium toward the brine solution. This difference could be due to the vacuum packaging technique used in this study. Significant changes in phosphor content of experimental cheeses was observed during storage time $(p<0.05)$. With a salt treatment phosphor contents changed irregularly in all cheeses during ripening.

Table 3. Sodium, calcium, potassium and phosphor content of White cheese samples made with different salt mineral replacers and stored for $90 \mathrm{~d}$.

\begin{tabular}{|c|c|c|c|c|c|c|}
\hline Attribute & Day & $\mathrm{K}$ & $\mathrm{L}$ & $\mathrm{M}$ & $\mathrm{N}$ & $P$ \\
\hline \multirow{4}{*}{$\begin{array}{l}\text { Sodium } \\
(\mathrm{mg} / 100 \mathrm{~g})\end{array}$} & 1 & $256.80 \pm 1.41^{\mathrm{Be}}$ & $147.07 \pm 3.88^{\mathrm{Ad}}$ & $128.65 \pm 3.53^{\mathrm{Ac}}$ & $121.50 \pm 14.14^{\mathrm{Ab}}$ & $66.35 \pm 2.33^{\text {Аa }}$ \\
\hline & 30 & $220.00 \pm 1.41^{\mathrm{Ac}}$ & $341.45 \pm 65.76^{\mathrm{Ce}}$ & $145.10 \pm 22.62^{\mathrm{Bb}}$ & $127.00 \pm 12.72^{\mathrm{Ba}}$ & $276.5 \pm 9.89 \mathrm{Dd}$ \\
\hline & 60 & $646.75 \pm 6.36^{\mathrm{Ce}}$ & $333.90 \pm 4.24^{\mathrm{Cd}}$ & $252.70 \pm 2.82^{\mathrm{Dc}}$ & $173.50 \pm 20.50^{\mathrm{cb}}$ & $163.8 \pm 5.65^{\mathrm{Ca}}$ \\
\hline & 90 & $664.85 \pm 3.53^{\mathrm{Dd}}$ & $248.90 \pm 1.41^{\mathrm{Bc}}$ & $248.35 \pm 17.67 \mathrm{Cc}$ & $214.8 \pm 1.41^{\mathrm{Db}}$ & $140.7 \pm 1.41^{\mathrm{Ba}}$ \\
\hline \multirow{4}{*}{$\begin{array}{l}\text { Calcium } \\
(\mathrm{mg} / \mathrm{l} 00 \mathrm{~g})\end{array}$} & 1 & $242.62 \pm 6.71^{\mathrm{Ab}}$ & $298.47 \pm 56.92^{\mathrm{Ad}}$ & $325.27 \pm 9.55^{\mathrm{Ae}}$ & $250.37 \pm 13.78^{\mathrm{Ac}}$ & $237.37 \pm 6.01^{\mathrm{Aa}}$ \\
\hline & 30 & $520.17 \pm 26.51^{\mathrm{De}}$ & $489.37 \pm 41.36^{\mathrm{Bd}}$ & $418.02 \pm 25.81^{\mathrm{Bb}}$ & $375.32 \pm 2.47^{\mathrm{Ca}}$ & $468.30 \pm 61.5 \mathrm{l}^{\mathrm{Cc}}$ \\
\hline & 60 & $460.07 \pm 29.34^{\mathrm{Cc}}$ & $578.52 \pm 37.12^{\mathrm{De}}$ & $491.57 \pm 14.49^{\mathrm{Cd}}$ & $358.07 \pm 28.63^{\mathrm{Ba}}$ & $431.40 \pm 23.33 \mathrm{~A}^{\mathrm{Bt}}$ \\
\hline & 90 & $451.90 \pm 24.04^{\mathrm{Bb}}$ & $527.10 \pm 6.36^{\mathrm{Cc}}$ & $538.02 \pm 14.49^{\mathrm{Dd}}$ & $370.45 \pm 29.69^{\mathrm{Ca}}$ & $456.975 \pm 53.38^{\mathrm{ch}}$ \\
\hline \multirow{4}{*}{$\begin{array}{l}\text { Potassium } \\
(\mathrm{mg} / \mathrm{l} 00 \mathrm{~g})\end{array}$} & 1 & $79.78 \pm 19.5 \mathrm{l}^{\mathrm{Aa}}$ & $100.66 \pm 36.52^{\mathrm{Ab}}$ & $165.82 \pm 80.96^{\mathrm{Bc}}$ & $272.50 \pm 25.45^{\text {ве }}$ & $229.65 \pm 4.95^{\mathrm{Bd}}$ \\
\hline & 30 & $310.57 \pm 15.91^{\mathrm{Cc}}$ & $199.45 \pm 4.94^{\mathrm{Cb}}$ & $334.47 \pm 28.63^{\mathrm{Dd}}$ & $114.47 \pm 11.66^{\mathrm{Aa}}$ & $194.90 \pm 99.7^{\mathrm{Ab}}$ \\
\hline & 60 & $142.72 \pm 51.97^{\mathrm{Bb}}$ & $189.92 \pm 13.08^{\mathrm{Cc}}$ & $93.17 \pm 23.72^{\mathrm{Aa}}$ & $381.02 \pm 37.12^{\mathrm{Cd}}$ & $431.25 \pm 23.33^{\mathrm{De}}$ \\
\hline & 90 & $143.87 \pm 52.68^{\mathrm{Ba}}$ & $135.00 \pm 89.09^{\mathrm{Ba}}$ & $269.07 \pm 36.42^{\mathrm{Cb}}$ & $439.40 \pm 60.10^{\mathrm{Dd}}$ & $396.77 \pm 21.56^{\mathrm{Cc}}$ \\
\hline \multirow{4}{*}{$\begin{array}{l}\text { Phosphor } \\
\text { (mg/100 g) }\end{array}$} & 1 & $169.80 \pm 38.18^{\mathrm{Ab}}$ & $98.35 \pm 3.32^{\mathrm{Aa}}$ & $114.30 \pm 8.06^{\mathrm{Aa}}$ & $102.50 \pm 1.91^{\mathrm{Aa}}$ & $88.30 \pm 1.06^{\mathrm{AAa}}$ \\
\hline & 30 & $163.10 \pm 3.60^{\mathrm{Ac}}$ & $144.00 \pm 8.34^{\mathrm{Bab}}$ & $156.30 \pm 2.54^{\text {Bab }}$ & $136.30 \pm 3.67^{\mathrm{Ba}}$ & $142.50 \pm 2.12^{\mathrm{Bab}}$ \\
\hline & 60 & $161.55 \pm 0.77^{\mathrm{Aa}}$ & $208.20 \pm 1.91^{\mathrm{Dc}}$ & $155.60 \pm 2.54^{\mathrm{Ba}}$ & $156.50 \pm 1.20^{\mathrm{Ca}}$ & $174.70 \pm 5.09^{\mathrm{Cb}}$ \\
\hline & 90 & $139.33 \pm 5.09^{\mathrm{Aa}}$ & $159.4 \pm 5.44 \mathrm{cb}$ & $177.50 \pm 12.02^{\mathrm{Bc}}$ & $143.40 \pm 4.17^{\mathrm{Bab}}$ & $148.80 \pm 1.27^{\mathrm{Bab}}$ \\
\hline
\end{tabular}

K: Control (100\% NaCl), L: $50 \% \mathrm{NaCl}, \mathrm{M}: 30 \% \mathrm{CaCl}_{2}+70 \% \mathrm{NaCl}, \mathrm{N}: 30 \% \mathrm{KCl}+70 \% \mathrm{NaCl}$, P: PanSalt.

Data are expressed as means \pm SD $p<0.05$. Means followed by different small letters in the row are significantly different $(p<0.05)$.

Means followed by different capital letters in the columns are significantly different $(\mathrm{p}<0.05)$. 


\section{Textural profile of cheese samples}

The hardness, cohesiveness, adhesiveness and gumminess results of White cheese kept in $\mathrm{NaCl}$ only and $\mathrm{NaCl}$ with different mineral salt replacements are presented in Table 4. The partial substitution of $\mathrm{NaCl}$ with different salt substitutes resulted in significant difference in hardness $(p<0.05)$ at the same storage time, whereas hardness values changed significantly among the cheeses salted with different salt mixtures except for month 3. All cheeses produced with $\mathrm{NaCl}-\mathrm{KCl}, \mathrm{NaCl}-\mathrm{CaCl}_{2}, \mathrm{NaCl}-\mathrm{KCl}-$ $\mathrm{MgSO}_{4}$ mixtures presented higher values for this parameter compared to the control cheese in the first 30 days of ripening. This is related to the decreased salt levels when salt substitutes were added. Also, $\mathrm{KCl}$ has a decreased ionic strength compared to $\mathrm{NaCl}$, which affects the solubility of proteins with a direct effect on the cheese matrix (Gomes et al., 2011). Additionally, hardness decreased significantly in cheeses manufactured with salt mix- tures compared with the control cheese during the ripening period (Grummer et al., 2012; Chamba and Debry, 1994). These findings may be related to the increase in proteolysis, probably because of enzymatic hydrolysis of as casein by the proteolytic enzymes and rennin. Indeed, in many cheese types, the protein matrix is converted into a softer structure during ripening (Al Otaibi and Wilbey, 2006; Gomes et al., 2011). The effect of reduced $\mathrm{NaCl}$ content on the quality of the cheese may also be related to other ingredients, especially the fat content (Gomes et al., 2011).

Cohesiveness is a measurement of the extent to which the cheese can be deformed before it ruptures (Dinkci et al., 2011). In sensory terms it is the degree to which a substance is compressed between the teeth before it breaks. In cheese, cohesiveness is a measurement of the strength of the internal bonds of the protein matrix (Chevanan et al., 2006). There are no significant changes among ripening

Table 4. Textural parameters of White cheese samples made with different salt mineral replacers and stored for $90 \mathrm{~d}$.

\begin{tabular}{|c|c|c|c|c|c|c|}
\hline Attribute & Day & $\mathrm{K}$ & $\mathrm{L}$ & M & $\mathrm{N}$ & $\mathrm{P}$ \\
\hline \multirow{4}{*}{$\begin{array}{l}\text { Hardness } \\
\text { (g) }\end{array}$} & 1 & $844.12 \pm 0.53^{\mathrm{Aa}}$ & $1142.12 \pm 7.24^{\mathrm{Ad}}$ & $930.37 \pm 3.35^{\mathrm{Bb}}$ & $1242.50 \pm 6.71^{\mathrm{Ce}}$ & $1006.00 \pm 5.30^{\mathrm{BCc}}$ \\
\hline & 30 & $873.50 \pm 10.96^{\mathrm{Ba}}$ & $1092.62 \pm 13.61^{\mathrm{Be}}$ & $958.50 \pm 2.47^{\mathrm{Cb}}$ & $1024.00 \pm 5.65^{\mathrm{Bd}}$ & $992.25 \pm 6.01^{\mathrm{Bc}}$ \\
\hline & 60 & $1020.12 \pm 7.24^{\mathrm{Cc}}$ & $948.62 \pm 1.59^{\mathrm{cb}}$ & $862.75 \pm 0.35^{\mathrm{Aa}}$ & $886.00 \pm 19.44^{\mathrm{Aa}}$ & $1026.25 \pm 1.06^{\mathrm{Cc}}$ \\
\hline & 90 & $967.25 \pm 7.24^{\mathrm{Db}}$ & $731.25 \pm 19.78^{\mathrm{Ca}}$ & $848.25 \pm 18.38^{\mathrm{Ab}}$ & $852.75 \pm 62.40^{\mathrm{Ab}}$ & $764.00 \pm 13.78^{\mathrm{Aa}}$ \\
\hline \multirow{4}{*}{$\begin{array}{l}\text { Cohesiveness } \\
\text { (mJ) }\end{array}$} & 1 & $0.34 \pm 0.31^{\mathrm{Aa}}$ & $0.57 \pm 0.22^{\mathrm{Aa}}$ & $0.32 \pm 0.29^{\mathrm{Aa}}$ & $0.39 \pm 0.39^{\mathrm{Aa}}$ & $0.31 \pm 0.28^{\mathrm{Aa}}$ \\
\hline & 30 & $0.36 \pm 0.34^{\mathrm{Aa}}$ & $2.11 \pm 0.69^{\mathrm{Bb}}$ & $0.25 \pm 0.05^{\mathrm{Aa}}$ & $0.47 \pm 0.19^{\mathrm{Aa}}$ & $0.91 \pm 1.07^{\mathrm{Aab}}$ \\
\hline & 60 & $0.18 \pm 0.00^{\mathrm{Aab}}$ & $0.26 \pm 0.02^{\mathrm{Abc}}$ & $0.13 \pm 0.02^{\mathrm{Aa}}$ & $0.35 \pm 0.06^{\mathrm{Ac}}$ & $0.2 \pm 0.03^{\mathrm{Aab}}$ \\
\hline & 90 & $0.32 \pm 0.02^{\mathrm{Aa}}$ & $0.39 \pm 0.12^{\mathrm{Aa}}$ & $0.20 \pm 0.02^{\mathrm{Aa}}$ & $0.29 \pm 0.04^{\mathrm{Aa}}$ & $0.45 \pm 0.16^{\mathrm{Aa}}$ \\
\hline \multirow{4}{*}{ Adhesiveness } & 1 & $0.28 \pm 0.01^{\mathrm{Ba}}$ & $0.40 \pm 0.06^{\mathrm{Bb}}$ & $0.28 \pm 0.02^{\mathrm{Ba}}$ & $0.27 \pm 0.04^{\mathrm{Aa}}$ & $0.22 \pm 0.00^{\mathrm{Aa}}$ \\
\hline & 30 & $0.21 \pm 0.06^{\mathrm{ABa}}$ & $0.20 \pm 0.01^{\mathrm{Aa}}$ & $0.22 \pm 0.02^{\mathrm{ABa}}$ & $0.23 \pm 0.04^{\mathrm{Aa}}$ & $0.21 \pm 0.01^{\mathrm{Aa}}$ \\
\hline & 60 & $0.18 \pm 0.00^{\mathrm{Aa}}$ & $0.24 \pm 0.01^{\mathrm{Aa}}$ & $0.18 \pm 0.05^{\mathrm{Aa}}$ & $0.35 \pm 0.07^{\mathrm{Ab}}$ & $0.2 \pm 0.02^{\mathrm{Aa}}$ \\
\hline & 90 & $0.39 \pm 0.02^{\mathrm{Aa}}$ & $0.20 \pm 0.02^{\mathrm{Aab}}$ & $0.20 \pm 0.00^{\mathrm{ABab}}$ & $0.27 \pm 0.01^{\mathrm{Ac}}$ & $0.23 \pm 0.02^{\mathrm{Abc}}$ \\
\hline \multirow{4}{*}{$\begin{array}{c}\text { Gumminess } \\
\text { (g) }\end{array}$} & 1 & $243.85 \pm 16.26^{\mathrm{Ba}}$ & $457.70 \pm 13.08^{\mathrm{Ac}}$ & $259.55 \pm 17.96^{\mathrm{Ba}}$ & $367.27 \pm 9.93^{\mathrm{Bb}}$ & $354.62 \pm 16.228^{\mathrm{Bb}}$ \\
\hline & 30 & $180.82 \pm 60.84^{\mathrm{ABa}}$ & $219.32 \pm 29.59^{\mathrm{Ba}}$ & $217.00 \pm 21.70^{\mathrm{ABa}}$ & $235.77 \pm 49.17^{\mathrm{Aa}}$ & $206.65 \pm 6.39^{\mathrm{Aa}}$ \\
\hline & 60 & $190.80 \pm 11.24^{\mathrm{ABab}}$ & $235.12 \pm 8.73^{\mathrm{Bab}}$ & $156.12 \pm 43.24^{\mathrm{Aa}}$ & $281.00 \pm 54.58^{\mathrm{Abb}}$ & $207.57 \pm 32.49^{\mathrm{Aab}}$ \\
\hline & 90 & $143.05 \pm 7.42^{\mathrm{Aa}}$ & $146.92 \pm 25.06^{\mathrm{Ca}}$ & $170.17 \pm 7.03^{\mathrm{Aa}}$ & $249.12 \pm 0.81^{\mathrm{Ab}}$ & $176.45 \pm 16.75^{\mathrm{Aa}}$ \\
\hline \multirow{4}{*}{$\begin{array}{l}\text { Chewness } \\
(\mathrm{mJ})\end{array}$} & 1 & $19.91 \pm 1.79^{\text {Аа }}$ & $37.46 \pm 3.51^{\mathrm{Bc}}$ & $21.87 \pm 1.48^{\mathrm{Bab}}$ & $28.09 \pm 4.08^{\mathrm{Bb}}$ & $19.01 \pm 1.24^{\mathrm{Aa}}$ \\
\hline & 30 & $13.33 \pm 6.00^{\mathrm{Aa}}$ & $18.33 \pm 2.31^{\mathrm{Aa}}$ & $17.46 \pm 1.30^{\mathrm{ABa}}$ & $17.73 \pm 3.60^{\mathrm{Aa}}$ & $16.70 \pm 0.87^{\mathrm{Aa}}$ \\
\hline & 60 & $15.17 \pm 0.16^{\mathrm{Aa}}$ & $16.10 \pm 1.00^{\mathrm{Aa}}$ & $13.55 \pm 4.47^{\mathrm{Aa}}$ & $19.59 \pm 1.03^{\mathrm{Aa}}$ & $15.88 \pm 2.46^{\mathrm{Aa}}$ \\
\hline & 90 & $25.81 \pm 0.62^{\mathrm{Aa}}$ & $11.85 \pm 1.98^{\mathrm{Ab}}$ & $14.15 \pm 1.60^{\mathrm{Aa}}$ & $20.13 \pm 0.00^{\mathrm{Aa}}$ & $13.96 \pm 2.40^{\mathrm{Aa}}$ \\
\hline
\end{tabular}

K: Control (100\% NaCl), L: $50 \% \mathrm{NaCl}, \mathrm{M}: 30 \% \mathrm{CaCl}_{2}+70 \% \mathrm{NaCl}, \mathrm{N}: 30 \% \mathrm{KCl}+70 \% \mathrm{NaCl}, \mathrm{P}:$ PanSalt.

Data are expressed as means $\pm \mathrm{SD} p<0.05$ Means followed by different small letters in the row are significantly different $(\mathrm{p}<0.05)$.

Means followed by different capital letters in the columns are significantly different $(\mathrm{p}<0.05)$. 
time except for L sample $(\mathrm{p}<0.05)$. Also, the cohesiveness of the L cheese was higher than the cheeses brined with different salt mixtures. These differences might be due to varying casein intermolecular associations in the cheese paracasein network, and the differences in the ionic strength of the salt mixtures used. Adhesiveness is defined as the work necessary to overcome attractive forces between the contacted surface of the cheese and the contacting surface of the probe. Analysis of variance showed that adhesiveness changed slightly among the cheeses manufactured with different salt mixtures $(\mathrm{p}>0.05)$ and also the same observation was reported during the storage period of the cheese sample ( $p>0.05)$. The difference found in adhesiveness may be linked to the cheese $\mathrm{pH}$, the degree of proteolysis and the different polar characteristics of the protein fraction and salt mixtures used.

Gumminess is defined as the energy needed to disintegrate a semi-solid food until it becomes ready for swallowing (Nateghi et al., 2012). The gumminess value did not significantly vary in cheeses samples $\mathrm{M}$ and $\mathrm{N}$ during the ripening period, whereas these values were determined to be significant in the L sample. Gumminess values were not significantly changed at the ninetieth day of storage and these values were reported to be similar at day 30 and day 60 of the storage ( $p>0.05)$.

Chewiness is defined as the number of chews (or amount of mastication) required for the consistency of a certain amount of sample to satisfactorily decrease, to allow swallowing (Nateghi et al., 2012). The chewiness value in the White cheese samples was not significantly different during the ripening period except for the L sample. Gumminess and chewiness values generally changed during ripening for the same salt treatment. This may be due to medium and small peptides - as a result of proteolysis - that increase water retention, which in turn, affects textural properties, particularly hardness, gumminess and chewiness (Ayyash et al., 2013). For the same salt treatment, hardness and gumminess decreased at the ninetieth day of storage in this study. These findings are in accordance with those of Katsiari and Voutsinas (1994), Katsiari et al. (1998), Ayyash et al. (2011, 2012, 2013), Gomes et al. (2011) Ayyash and Shah (2011a), Grummer et al. (2012), for Kefalograviera and Domiati, Halloumi, Akawi, Mozzarella, Nabulsi, Minas and Cheddar cheeses. This trend may be attributed to two reasons. Firstly, the decrease in calcium during storage led to a reduction in cross linkages between caseins. The $\mathrm{Ca}$ decrease is related to $\mathrm{Ca}$ ion diffusion in the brine solution that may cause a decrease in colloidal Ca which, in turn, increases cheese softening. Secondly, the increase in proteolysis during storage hydrolyzed the protein and softened the cheese matrix (Guinee et al., 2002; Ayyash et al., 2011). Adhesiveness and cohesiveness changes may be due to the decrease in $\mathrm{Ca}$ and increase in proteolysis during storage. This, in turn, increases small peptides in the serum phase (Bhaskaracharya and Shah, 2001). Also it has been assumed that these differences in textural characteristics may be attributed to differences between cheese blocks as mentioned by Ayyash et al. (2012) in Akawi cheese.

\section{Conclusions}

To reduce sodium consumption in White cheese, some mineral-based salts were tested as a salt $(\mathrm{NaCl})$ replacement. Some physicochemical and textural profile analyses were performed on White cheeses produced with different salt treatments. In comparison to the control $(\mathrm{NaCl})$, this substitution showed no significant effect on the comprehensive parameters evaluated. The $\mathrm{Na}, \mathrm{K}, \mathrm{Ca}$ and $\mathrm{P}$ content showed important differences across the cheese samples. The total sodium content of $\mathrm{L}, \mathrm{M}, \mathrm{N}$ and P samples decreased significantly. As a result, White cheese was produced without visible defects using some salt replacements.

\section{Utjecaj zamjene mineralne soli na svojstva turskog bijelog sira}

\section{Sažetak}

U ovom istraživanju ispitana je primjena različitih kombinacija mineralnih soli kao zamjena za natrijev klorid u proizvodnji turskog bijelog sira te se ispitivao njihov učinak na fizikalna, kemijska i teksturalna svojstva uzoraka sira. U proizvodnji sira korišteno je pet vrsta slanih otopina sastavljenih od samo $\mathrm{NaCl}$ (K: kontrola) (16 
$\% \mathrm{w} / \mathrm{w})$ odnosno od $50 \% \mathrm{NaCl}$ (L) (8 \% w/w), $30 \% \mathrm{CaCl}_{2}$ i $\left.70 \% \mathrm{NaCl}(\mathrm{M}) 16 \% \mathrm{w} / \mathrm{w}\right)$, te od $30 \% \mathrm{KCl}$ i $70 \% \mathrm{NaCl}(\mathrm{N})(16 \% \mathrm{w} / \mathrm{w})$ kao i komercijalni pripravak PanSalt (P) (16\% w/w). PanSalt $(57 \% \mathrm{NaCl}+28 \% \mathrm{KCl}+12 \% \mathrm{MgS} 04)$ je komercijalna sol s niskim udjelom natrija. $U$ istraživanju su određivana sljedeća svojstva sireva: ukupna suha tvar, pepeo, proteini, mliječna mast, sol, tiitracijska kiselost, $\mathrm{pH}$ vrijednost, udio dušika topivog u vodi, udio dušika topivog u trikloroctenoj kiselini, udio dušika iz frakcije proteoze peptona, udjel natrija, kalcija, kalija, fosfora i magnezija te teksturalna svojstva (putem analize profila teksture). U usporedbi s kontrolnim sirom, ispitivane zamjene za natrijev klorid nisu pokazale značajan učinak na ocjenjivane parametre. Udjeli Na, K, Ca i P pokazali su značajne razlike među uzorcima sira. Ukupni udjel natrija u uzorcima L, M, N i P značajno se smanjio. Na osnovi rezultata dobivenih ovim istraživanjem može se zaključiti kako je moguće proizvesti sir sa smanjem sadržajem natrija uz korištenje odgovarajuće količine zamjena za mineralne soli.

Ključne riječi: turski bijeli sir, zamjena mineralne
soli, proteoliza, niska razina natrija

\section{References}

1. Al Otaibi, M.M., Wilbey, A. (2006): Effect of chymosin reduction and salt substitution on the properties of white salted cheese. International Dairy Journal 16 (8), 903-909. https://doi.org/10.1016/j.idairyj.2005.08.006

2. Aly, M.E. (1995): An attempt for producing low-sodium Feta-type cheese. Food Chemistry 52 (3), 295-299. https://doi.org/10.1016/0308-8146(95)92827-7

3. Anonymous. (2002): Diet, physical activity and health. Geneva. World Health Organization. Available at: https://www.who.int/nutrition/topics/2_background/en/

4. Anonymous. (2006): TS 591 Beyaz Peynir Standard. TSE, Ankara.

5. Anonymous. (2011): Program of excess salt consumption. Ministry of Health, Turkey. Edition Number: 835.

6. AOAC. (2000): Official Methods of Analysis. 17th. Edn. (W. Horwitz. Ed.). Association of Official Analytical Chemists International. Gaithersburg. MD. USA.

7. Arakawa, T., Timasheff, S.N. (1984): Mechanism of protein salting in and salting out by divalent cation salts: balance between hydration and salt binding. Biochemistry 23 (25), 5912-5923. https://doi.org/10.1021/bi00320a004

8. Ardö, Y. (1999): Evaluating proteolysis by analysing the $\mathrm{N}$ content of cheese fractions. Bulletin of Int. Dairy Federation 337, 4-9.
9. Ayyash, M.M., Shah, N.P. (2010): Effect of partial substitution of $\mathrm{NaCl}$ with $\mathrm{KCl}$ on Halloumi cheese during storage: Chemical composition. lactic bacterial count and organic acids production. Journal of Food Science 75 (6), 525-529. https://doi.org/10.1111/j.1750-3841.2010.01691.x

10. Ayyash, M.M.F., Sherkat, P., Francis, R.P., Williams, W., Shah, N.P. (2011): The effect of sodium chloride substitution with potassium chloride on texture profile and microstructure of Halloumi cheese. Journal of Dairy Science 94, 37-42. https://doi.org/10.3168/jds.2010-3407

11. Ayyash, M.M., Shah, N.P. (2011a): The effect of substituting $\mathrm{NaCl}$ with $\mathrm{KCl}$ on Nabulsi cheese: Chemical composition, total viable count and texture profile. J. Dairy Science 94, 2741-2751. https://doi.org/10.3168/jds.2010-3976

12. Ayyash, M.M., Shah, N.P. (2011b): The effect of substitution of $\mathrm{NaCl}$ with $\mathrm{KCl}$ on chemical composition and functional properties of low-moisture Mozzerella cheese. Journal of Dairy Science 94, 3761-3768. https://doi.org/10.3168/jds.2010-4103

13. Ayyash, M.M, Shah, N.P. (2011c): Proteolysis of low moisture Mozzarella cheese as affected by substitution of $\mathrm{NaCl}$ with KCl. Journal of Dairy Science 94 (8), 3769-3777. https://doi.org/10.3168/jds.2010-4104

14. Ayyash, M.M., Sherkat, F., Shah, N.P. (2012): The effect of $\mathrm{NaCl}$ substitution with $\mathrm{KCl}$ on Akawi cheese: Chemical composition, proteolysis, angiotensin-converting enzyme-inhibitory activity, probiotic survival, texture profile and sensory properties. Journal of Dairy Science 95 (9), 4747-4759. https://doi.org/10.3168/jds.2011-4940

15. Ayyash, M.M., Sherkat, F., Shah, N.P. (2013): Effect of partial $\mathrm{NaCl}$ substitution with $\mathrm{KCl}$ on the texture profile, microstructure and sensory properties of low moisture Mozzarella cheese. Journal of Dairy Research 80 (1), 7-13. https://doi.org/10.1017/S002202991200043X

16. Bhaskaracharya, R.K., Shah, A. (2001): Texture and microstructure of skim milk Mozzarella cheeses made using fat replacers. Australian Journal of Dairy Technology 56 (1), 9-14

17. Chamba, J.F., Debry, G. (1994): Caracte' ristiques et acceptabilite' d'emmentals hyposode's. Sciences des Aliments 14, 335-348.

18. Chevanan, N., Muthukumarappan, K., Upreti, P., Metzger, L.E. (2006): Effect of calcium and phosphorus, residual lactose and salt-to-moisture ratio on textural properties of cheddar cheese during ripening. Journal of Texture Studies 37, 711-730. https://doi.org/10.1111/j.1745-4603.2006.00080.x

19. Creighton, T.E. (1993): Proteins, structure and molecular properties. Freeman. New York.

20. Dinkci, N., Kesenkaş, H., Seçkin, K., Kınık, Ö., Gönç, S. (2011): Influence of a vegetable fat blend on the texture, microstructure and sensory properties of kashar cheese. Grasas y Aceites 62 (3), 275-283. https://doi.org/10.3989/gya.091810 
21. Dorosti, S., Bazmi, A., Ghanbarzadeh, B., Ayaseh, A. (2010): Effect of partial replacement of $\mathrm{NaCl}$ with $\mathrm{KCl}$ in cheese-making brine on characteristics of Iranian white cheese. Iranian J. Nutr. Sci. \& Food Technol. 5, 67-74.

22. El-Bakry, M., Beninati, F., Duggan, E., O'Riordan, E.D., O'Sullivan, M. (2011): Reducing salt in imitation cheese: Effects on manufacture and functional properties. Food Research International 44, 589-586. https://doi.org/10.1016/j.foodres.2010.12.013

23. Fitzgerald, E., Buckley, J. (1985): Effect of total and partial substitution of sodium chloride on the quality of Cheddar Cheese. Journal of Dairy Science 68 (12), 3127-3134. https://doi.org/10.3168/jds.S0022-0302(85)81217-0

24. Fox, P.F., Mcsweeney, P.L.H. (1996): Proteolysis in cheese during ripening. Food Rev. Int. 12, 457-509. https://doi.org/10.1080/87559129609541091

25. Gomes, A.P., Cruz, A.G., Cadena, R.S., Celeghini, R.M.S., Faria, J.A.F., Bolini, H.M.A., Pollonio, M.A.R., Granato, D. (2011): Manufacture of lowsodium Minas fresh cheese: effect of the partial replacement of sodium chloride with potassium chloride. Journal of Dairy Science 94 (6), 2701-2706. https://doi.org/10.3168/jds.2010-3774

26. Grummer, J., Karalus, M., Zhang, K., Vickers, Z., Schoenfuss, T.C. (2012): Manufacture of reducedsodium Cheddar-style cheese with mineral salt replacers. Journal of Dairy Science 95, 2830-2839. https://doi.org/10.3168/jds.2011-4851

27. Guinee, T.P., Feeney, E.P., Auty, M.A.E., Fox, P.F. (2002): Effect of $\mathrm{pH}$ and calcium concentration on some textural and functional properties of Mozzerella cheese. Journal of Dairy Science 85, 1655-1659. https://doi.org/10.3168/jds.S0022-0302(02)74238-0

28. Guinee, T.P., Fox, P.F. (2004): Salt in cheese: Physical. chemical and biological aspects. General aspects in Cheese: Chemistry physics and microbiology (pp. 207259). Elsevier Academic Press. London. UK.

29. Johnson, M.E., Kapoor, R., McMahon, D.J., McCoy, D.R., Narasimmon, R.G. (2009): Reduction of sodium and fat levels in natural and processed cheeses: Scientific and technological aspects. Comprehensive Reviews in Food Science and Food Safety 8, 252-268. https://doi.org/10.1111/j.1541-4337.2009.00080.x

30. Kaplan, N.M. (2000): The dietary guideline for sodium: should we shake it up? The American Journal of Clinical Nutrition 71 (5), 1020-1026.

31. Karagözlü, C., Kıntk, Ö., Akbulut, N. (2008): Effects of fully and partial substitution of $\mathrm{NaCl}$ by $\mathrm{KCl}$ on physicochemical and sensory properties of white cheese. International Journal Food Science Nutrition 59, 181-191. https://doi.org/10.1080/09637480701453553

32. Katsiari, M.C., Voutsinas, L.P. (1994): Manufacture of Low Fat Feta Cheese. Food Chemistry 49. 53-60. https://doi.org/10.1016/0308-8146(94)90232-1

33. Katsiari, M.C., Voutsınasi, L.P., Alıchanıdıs, E., Roussis, I. G. (1997): Reduction of sodium content in Feta cheese by partial substitution of $\mathrm{NaCl}$ by KCl. International Dairy Journal 7, 465-472. https://doi.org/10.1016/S0958-6946(97)00032-0
34. Katsiari, M.C., Voutsinas, L.P., Alıchanıdıs, E., Roussis, I.G. (1998): Manufacture of Kefalograviera cheese with less sodium by partial replacement of $\mathrm{NaCl}$ with KCl. Food Chemistry 6 (1-2), 63-70. https://doi.org/10.1016/S0308-8146(97)00113-1

35. Katsiari, M.C., Alichanidis, E., Voutsinas, L.P., Roussis, I.G. (2000a): Proteolysis in reduced sodium feta cheese made by partial substitution of $\mathrm{NaCl}$ by $\mathrm{KCl}$. International Dairy Journal 10, 635-646. https://doi.org/10.1016/S0958-6946(00)00097-2

36. Katsiari, M.C., Voutsinas, L.P., Alichanidis, E., Roussis, I.G. (2000b): Lipolysis in reduced sodium Feta cheese made by partial substitution of $\mathrm{NaCl}$ by $\mathrm{KCl}$. International Dairy Journal 10, 369-373. https://doi.org/10.1016/S0958-6946(00)00067-4

37. Katsiari, M.C., Alichanidis, E., Voutsinas, L.P., Roussis, I.G. (2001): Proteolysis in reduced sodium Kefalograviera cheese made by partial replacement of $\mathrm{NaCl}$ with KCl. Food Chemistry 73, 31-43. https://doi.org/10.1016/S0308-8146(00)00275-2

38. Mattes, R.D., Donnely, D. (1991): Relative contributions of dietary sodium sources. Journal of the American College of Nutrition 10, 383-393. https://doi.org/10.1080/07315724.1991.10718167

39. Mei, J., Guo, Q., Wu, Y., Li, Y., Yu, H. (2015): Study of proteolysis. Lipolysis and volatile compounds of a Camamber-type cheese manufactured using a freeze-dried Tibetan kefir co-culture during ripening. Food Science Biotechnology 24 (2), 393-402. https://doi.org/10.1007/s10068-015-0052-9

40. Nateghi, L., Roohinejad, S., Totosaus, A., Mirhosseini, H., Shuhaimi, M., Meimandipour, A., Omidizadeh, A., Abd-Manap, M. Y. (2012): Optimization of textural properties and formulation of reduced fat Cheddar cheeses containing fat replacers. Journal of Food, Agriculture and Environment 10 (2), 46-54.

41. Petik, S. (1987): Reduced sodium cultured dairy products. Cultured Dairy Products Journal of the American Cultured Dairy Products Institute 22, 12-14.

42. Reddy, K.A., Marth, E.H. (1995): Microflora of Cheddar cheese made with sodium chloride potassium chloride or mixtures of sodium and potassium chloride. Journal of Food Protection 58 (1), 54-61. https://doi.org/10.4315/0362-028X-58.1.54

43. Renner, E. (1993): Milchpraktikum Skriptum zu den Übungen. Giessen. Germany: Justus Liebig Universität.

44. Shabab Lavasani, R., Ehsani, M.R. (2012): Effect of Bifidobacterium lactis on free fatty acids of Lighvan cheese during ripening. Journal of Medical and Bioengineering (1), 4-6. https://doi.org/10.12720/jomb.1.1.4-6

45. Tarakci, Z., Kucukoner, E. (2006): Changes on physicochemical, lipolysis and proteolysis of vacuumpacked Turkish Kashar cheese during ripening. Journal Central European Agriculture 7 (3), 459-464.

46. Upadhyay, V.K., McSweeney, P.L.H., Magboul, A.A.A., Fox, P.F. (2004): Proteolysis in cheese during ripening. Cheese: Chemistry. Physics and Microbiology 1, 391433. 